\title{
Association between haematological parameters and sickle cell genotypes in children with Plasmodium falciparum malaria resident in Kisumu County in Western Kenya
}

\author{
Paul Kosiyo ${ }^{1,2}$, Walter Otieno ${ }^{3}$, Jesse Gitaka ${ }^{4}$, Elly O. Munde ${ }^{5}$ and Collins Ouma ${ }^{1 *}$
}

\begin{abstract}
Background: Sickle cell disease (SCD) is a monogenic disorder due to point mutation in the $\beta$-globin gene resulting in substitution of Valine for Glutamic acid. The SCD is prevalent in P. falciparum endemic regions such as western Kenya. Carriage of different sickle cell genotypes may influence haematological parameter during malaria. Children resident in malaria holoendemic regions suffer more from malaria-related complications and this is moderated by the presence of the SCD. In the current study, we determined the association between sickle cell genotypes and haematological parameters in children with P. falciparum malaria resident in Kisumu County in Western Kenya.

Methodology: Children ( $n=217$, aged 1-192 months) with acute febrile condition were recruited at Jaramogi Oginga Odinga Teaching and Referral Hospital. Chi-square (x2) analysis was used to determine differences between proportions. Differences in haematological parameters were compared across groups using Kruskal Wallis test and between groups using Mann Whitney $U$ test. Multivariate logistic regression analysis controlling for infection status was used to determine the association between sickle cell genotypes and haematological parameters.

Results: Using HbAA as the reference group, multivariate logistic regression analysis revealed that carriage of HbSS was associated with reduced haemoglobin $[\mathrm{OR}=0.310,95 \% \mathrm{Cl}=0.101-0.956, P=0.041]$, reduced haematocrit $[\mathrm{OR}=0.318,95 \% \mathrm{Cl}=0.128-0.793, P=0.014]$, reduced $\mathrm{RBC}$ count $[\mathrm{OR}=0.124,95 \% \mathrm{Cl}=0.045-0.337, P=0.001]$, reduced $\mathrm{MCHC}[\mathrm{OR}=0.325,95 \% \mathrm{Cl}=0.118-0.892, P=0.029]$, increased leucocytosis $[\mathrm{OR}=9.283,95 \% \mathrm{Cl}=3.167$ 27.210, $P=0.001]$ and reduced monocytosis $[\mathrm{OR}=0.319,95 \% \mathrm{Cl}=0.123-0.830, P=0.019]$. However, carriage of HbAS was only associated with increased micro-platelets [OR $=3.629,95 \% \mathrm{Cl}=1.291-8.276, P=0.012]$.

Conclusion: Results show that carriage of HbSS in children influence the levels of haemoglobin, haematocrit, RBC, MCHC, WBC and Monocytes. Therefore prior knowledge of HbSS should be considered to improve clinical management of haematological alterations during malaria in children.
\end{abstract}

Keywords: Sickle cell, Genotype, Malaria, Plasmodium falciparum, Haemoglobin

\footnotetext{
* Correspondence: collinouma@yahoo.com

'Department of Biomedical Science and Technology, School of Pub;ic Health and Community Development, Maseno University, Maseno, Kenya Full list of author information is available at the end of the article
}

C C The Author(s). 2020 Open Access This article is licensed under a Creative Commons Attribution 4.0 International License, which permits use, sharing, adaptation, distribution and reproduction in any medium or format, as long as you give appropriate credit to the original author(s) and the source, provide a link to the Creative Commons licence, and indicate if changes were made. The images or other third party material in this article are included in the article's Creative Commons licence, unless indicated otherwise in a credit line to the material. If material is not included in the article's Creative Commons licence and your intended use is not permitted by statutory regulation or exceeds the permitted use, you will need to obtain permission directly from the copyright holder. To view a copy of this licence, visit http://creativecommons.org/licenses/by/4.0/ The Creative Commons Public Domain Dedication waiver (http://creativecommons.org/publicdomain/zero/1.0/) applies to the data made available in this article, unless otherwise stated in a credit line to the data. 


\section{Background}

The sickle cell haemoglobin $(\mathrm{HbS})$ is a genetic disorder due to a single nucleotide polymorphism (SNP) or a point mutation substituting thymine for adenine at the sixth codon of $\beta$ gene, (6GAG > 6GTG). This leads to valine incorporation, rather than glutamine and results in haemoglobin tetramers $(\mathrm{HbS})$ that aggregate into arrays upon deoxygenation in the tissues [1]. The resulting $\mathrm{HbS}$ forms long polymers in reduced oxygen tension due hydrophobic interaction of valine (at 85th position of the globin chain) and phenylalanine (at 88th position of the globin chain) [2]. The involved red blood cells (RBC) ultimately become less flexible since polymers lead to biochemical and rheological changes forming aggregates hence impair the blood flow causing vaso-occlusion which is the hallmark of this genetic disorder [3].

Sickle cell disease refers to a group of autosomal recessive genetic disorders characterized by the presence of $\mathrm{HbS}$ mutated allele of the globin chain, whereas the wild type is called the HbA allele $[4,5]$. On the other hand, sickle cell trait (HbAS) is the heterozygous form of sickle cell disease where the individual is a carrier of the $\mathrm{HbS}$ (sickle cell) gene [4]. The global impact of sickle cell disease (SCD) has been estimated to be approximately 275 , 000 births per year [6] and it is equally approximated that it could reach 400,000 births by 2050 in regard to recent projections [7]. Africa is the most affected continent with sickle cell trait (SCT) prevalence being greater than $15 \%$ in Sub-Saharan Africa [8]. The geographical distribution of these SCD is very similar to that of malaria and it has been found that SCT confers some resistance to malaria $[9,10]$. The aetiological agent of malaria is the protozoan organism, Plasmodium of which the main species is falciparum [11]. In areas of $P$. falciparum malaria holo-endemicity such as Kisumu in Western Kenya, malaria contributes to $63.4 \%$ of admissions in children less than 5 years [12]. Due to this protection associated with SCT, these disorders have reached a balanced polymorphism in malaria holo-endemic regions such as in Kisumu County in western Kenya [13, 14]. It is thought that SCD make the cell susceptible to haemolysis at reduced thresholds of oxygen and any interior or exterior stressors on the RBC can simply make them haemolyse [14]. Worse still, malaria is the most important parasitic disease of humans and claims the life of more children globally than any other infectious disease [15]. This has clearly led to the hypothesis that this mutation is driven a lot by the pressure resulting from malaria parasite [16-18]. Presently, it is well documented that P. falciparum is a driving force of evolution that has shaped the human genome and can select genes that contribute to resistance $[16,17]$. Whenever a gene that has a potential for reducing fitness achieves high frequencies in the population, it is assumed that the gene confers a survival advantage [19]. Sufficient studies including the ones conducted in the same locality in Western Kenya and elsewhere, have demonstrated that individuals who are heterozygous for the $\mathrm{HbS}$ are protected from the severe form of malaria infection [9, 14, 20, 21]. Malaria confers a selective heterozygous survival advantage to carriers of the $\mathrm{HbS}$ gene and this is referred to as balanced polymorphism [18]. Based on previous studies, it is plausible that both $P$. falciparum malaria and sickle cell disease have independent significant impacts on the alteration of haematological parameters [21-24].

Haematological parameters have been used over the years as pointers in the diagnosis of both infectious and non-infectious diseases and more specifically haemoglobinopathies [25]. These haematological parameters include both blood cell indices such as mean cell haemoglobin $(\mathrm{MCH})$, red cell distribution width (RDW) as well as mean cell haemoglobin concentration $(\mathrm{MCHC})$ and primary red cell measurement such as red cell count, haematocrit and mean cell volume (MCV). Even though SCD is primarily a disease of red blood cells, both leucocytes and thrombocytes are equally affected [26]. The above-mentioned indices together with other parameters such as platelet count, mean platelet volume (MPV) and platelet distribution width (PDW) as well as leucocyte count are of major diagnostic significance and are equally important in the management of SCD and pathogenesis of the various sickle cell crises [3, 27]. It is therefore imperative to determine the association between the haematological parameters and sickle cell genotypes in Plasmodium falciparum malaria infection because these haematological parameters determine the occurrence of various sickle cell crises as demonstrated by vaso-occlusion [3, 27]. However, few studies in East Africa and none in Kenya has been undertaken to elucidate the association of these haematological parameters and sickle cell genotypes in $P$. falciparum infection [28]. Recently, a retrospective study involving patients with severe malaria in Cameroon did not find any significant association between these parameters and SCD [29], however, leucocytosis and thrombocytosis have been previously reported to drive sickle cell crises $[27,30]$. To bridge this knowledge gap, our study aimed to determine the association between haematological parameters and sickle cell genotypes in children with $P$. falciparum infection enrolled at Jaramogi Oginga Teaching and Referral Hospital (JOOTRH), in Kisumu County within western Kenya.

\section{Methods}

Study Site: The study was conducted at Jaramogi Oginga Odinga Teaching and Referral Hospital (JOOTRH) in Kisumu County between April 2018 and February 2019. 
JOOTRH is a level 5 hospital located within the headquarter of Kisumu County in Western Kenya and within Kisumu East Sub-County with a population of 150,124 in an area of $135.90 \mathrm{~km} 2$ [31]. This facility is the major referral health facility in Western Kenya for a greater population of 968,909 in an area of $2085.9 \mathrm{~km}^{2}$ [31]. Kisumu County is a malaria endemic area with prevalence at $27 \%$ [32]. Kisumu County has seven sub-counties namely Kisumu East, Kisumu West, Kisumu Central, Muhoroni, Seme, Nyando and Nyakach [31]. An earlier study in this site reported that the percentage of children aged below 5 years who had the SCT was $17.4 \%$ [13]. Furthermore, it has been confirmed that despite intensive malaria control approaches, this region show an increasing trend of malaria infection [33].

\section{Study population}

This was a cross-sectional study targeting children aged 1-192 months and resident within Kisumu County. The sample size was calculated based on prevalence of sickle cell trait in the study area [13] using Cochran's formula [34]. This period was selected since it captured the two major periods of the long and short seasonal rains from April to August and from November to December, respectively [35]. Furthermore, the period of enrolment was when the annual inoculation rates are usually high and estimated to be 300 infective bites per person per annum [35]. Throughout sampling, and even presently, there was neither routine screening for SCD in any place in Kenya nor any explicit nationally based guidelines regarding management of SCD. A validated structured questionnaire including demographic information, history of previous blood transfusion, and previous history of crises was administered prior to recruitment (See Supplementary File 1). All sickle cell patients were either on or not on routine tablets used in sickle cell clinics like vitamin B complex, paludrine and folic acids. No participant was on hydroxyurea therapy which could have impacted on the reported results for the sickle cell patient group.

\section{Inclusion criteria}

Children in steady state and found to be infected with $P$. falciparum upon demonstration of asexual forms of $P$. falciparum through microscopic examination of both thick and thin smear with haemoglobin phenotype SS, AS and AA. Only participants who were HIV negative were included in the study. Besides meeting the above criteria, only children /patients whose parents were willing and able to provide written informed consent were included in the study.

\section{Exclusion criteria}

Children with other forms of haemoglobinopathies e.g. thalassaemia syndromes. Participants with history of crises in the past 3 months, established by a careful history and complete physical examination as well as those with history of blood transfusion in the past 3 months were excluded. Those with acute bacterial, viral infections and parasitic infections other than P. falciparum and those with any form of malignancy were also excluded. Known sickle cell patients on hydroxyurea therapy were equally excluded.

\section{Ethical consideration}

This study received ethical approval from Jaramogi Oginga Odinga Teaching and Referral Hospital Scientific and Ethics Review Committee (JOOTRH-ERC) - Approval NO. ERC.IB/VOL.1/414. An informed, written and voluntary consent was sought from the parents/ guardians of children before obtaining blood samples for testing. Wherever applicable, children's assent was also registered. The consent included strict confidentiality of the information generated during the study and their use for research.

\section{Laboratory procedures \\ Haematological measurements}

Haemoglobin $(\mathrm{Hb})$ levels and complete blood counts were determined using the Beckman Coulter ACT diff2 $2^{\mathrm{m}}$ (Beckman-Counter Corporation, Miami, FL, USA) in accordance to local Standard Operating Procedures (SOPs) within one hour of blood collection. Routine Quality Assurance checks were performed using commercial controls and recorded in conformity to manufacturer's recommendations for the blood counts. The Analyser provided data on WBCs, RBCs, mean cell volume (MCV), haemoglobin level, platelet counts, mean platelet volume (MPV), platelet distribution width, (PDW) red cell distribution width (RDW) and three part differentials. The Analyser also detected and flagged platelet aggregation and cold agglutinins based on the particle size using a 256-channel pulse-height analyser of platelet histogram region.

\section{Blood smears}

Approximately $10 \mu \mathrm{l}$ of blood was used for preparation of thick film while $2 \mu \mathrm{l}$ of blood was used for thin smears. Thick smears were air-dried and stained with $10 \%$ Giemsa (Sigma-Aldrich, Germany) while thin smears were first fixed in absolute ethanol (Sigma-Aldrich, Germany) before staining with $10 \%$ Giemsa. After staining, a minimum of 50 high power fields (HPF) were scanned for a positive smear and $200 \mathrm{HPF}$ for a negative by experienced Laboratory technologist. Diagnosis of malaria was based on the detection of asexual form of P. falciparum (trophozoite or 
schizont) of any density in the thick film. Thin blood films were further used for speciation of the Plasmodium species and for cytomorphological study of blood cell upon any flagging of haematological parameter in the complete blood picture due to platelet aggregation and cold agglutinins.

\section{DNA extraction and quantification}

Genomic DNA for sickle cell genotyping was extracted from $200 \mu \mathrm{L}$ of whole blood. PureLink ${ }^{\bullet}$ DNA Mini Kit, (Invitrogen life technologies, USA) was used for DNA extraction following manufacturer's instructions. The extraction procedure involved 4 major steps: Preparation of blood lysates, DNA binding, DNA washing and elution of $50 \mu \mathrm{L}$ of DNA as per the manufacturer's instructions. DNA quality and quantity was assessed using Nano Drop ND-1000 spectrophotometer (Thermofisher Scientific, San Diego, CO, USA) and stored at $-200 C$.

\section{Sickle cell genotyping}

Functionally tested TaqMan SNP Genotyping Assay was used in accordance with the manufacturer protocols (Life Technologies, Grand Island, NY). Identification of haemoglobin $\mathrm{S}$ was from biallellic discrimination (missense change [Glu6VAL) in the single nucleotide polymorphism rs334 by the following primer and probe sequences: Forward-TCAAACAGACACCATGGTGCAT, ReverseCCCCACAGGGCAGTAACG, VIC-CTGACTCCTGAG GAGAA-MGB, 6FAM-CTGACTCCTGTGGAGAA-MGB, respectively. For quality assurance, a triplicate of control sample for genotype HbAA, HbAS and HbSS were run. Amplification was performed in Real-time PCR StepOnePlus thermo cycler from Applied Biosystems ${ }^{\circ}$ (Foster City, CA, USA) through an initial denaturation at $950 \mathrm{C}$ for 10 min, followed by 40 cycles of denaturation at $950 \mathrm{o}$ for 1 $\mathrm{min}$, annealing at $60 \mathrm{oC}$ for $1 \mathrm{~min}$ and final annealing at $60 \mathrm{oC}$ for $1 \mathrm{~min}$.

\section{Statistical analyses}

Statistical analyses were executed using Statistical Package for the Social Sciences (SPSS) version 22.0 software (IBM, New York, USA). Chi-square $\left(\chi^{2}\right)$ analysis was used to determine differences between proportions. Mann-Whitney $U$ test or student's t-test was used for comparisons of demographic and laboratory characteristics between the clinical groups. Kruskal Wallis test was used to compare levels of haematological parameters across the haemoglobin genotypes. Association between haematological parameters and sickle cell genotypes was determined using multivariate logistic regression while association between sickle genotype and $P$. falciparum infection was determined by bivariate logistic regression. All statistical significance was set at $P \leq 0.05$.

\section{Results}

Clinical, laboratory and demographic characteristics of study participants

Children ( $n=217$, aged $1-192$ months) presenting with acute febrile conditions (temperature $>37.5 \mathrm{oC}$ ) were recruited in the study. Out of these, 100 were females while 117 were males (See Supplementary File 2). A total of 148 (66 females and 82 males) had HbAA genotype, 45 (22 males and 23 females) had HbAS and 24 (13 females and 11 males) had HbSS genotype. The proportions of sex with regard to malaria infection between the clinical groups in each genotype stratum were comparable $(P=0.964, P=0.921$ and $P=0.167)$ for genotypes HbAA, HbAS and HbSS, respectively. Across group comparison on sex distribution demonstrated that this was also comparable across the genotypes $(P=0.880)$. Malaria of any parasite density, (asexual form of $P$. falciparum trophozoite or schizont) was microscopically confirmed in $58 \mathrm{HbAA}, 14 \mathrm{HbAS}$ and $13 \mathrm{HbSS}$ with genotype-specific prevalence of $39.2 \%$ (58/148), 31.1\% $(14 / 45)$ and $54.2 \%(13 / 24)$, respectively. The remaining children (90 HbAA, $31 \mathrm{HbAS}$ and $11 \mathrm{HbSS}$ ) were $P$. falciparum negative. In the HbAA group, children with $P$. falciparum infection group [median (IQR); 36 (63.3)] were older compared to those in non-infected group [median (IQR); 29.5 [36], $P=0.022$ ]. Otherwise age did not differ between infected and non-infected groups both in HbAS [median (IQR); 36.3 (32.3)] and [median (IQR); 36 [37], $P=0.731$ ] and HbSS [median (IQR); 31 (76)] and [median (IQR); 16 [27], $P=0.569$ ], respectively. Haematological parameters were compared in the infected and non-infected children (controls) of the equal genotype (within the group) and in the infected children of different genotypes (across the group) i.e. HbAS versus HbSS. As shown in Table 1, haemoglobin $(P=0.001)$, haematocrit $(P=0.001)$ and $\mathrm{RBC}(P=0.004)$ count were relatively lower in the infected group compared to non-infected group within each genotype. The RDW $(P=0.007)$ was moderately higher in the infected group compared to non-infected group in each stratum. Haemoglobin, haematocrit, RBC count and RDW were the most significantly different red cell parameter across the genotypes $(P=0.001, P=0.001, P=0.004$ and $P=$ 0.007 , respectively). Furthermore, MCV $(P=0.332)$, $\mathrm{MCH}(P=0.784)$ and $\mathrm{MCHC}(P=0.179)$ were higher in the non-infected group relative to infected group in each genotype.

Even though the WBC count were numerically lower in the infected group relative to non-infected group in HbAA genotype $(P=0.817)$ but higher in the infected group within both $\mathrm{HbAS}(P=0.433)$ and $\operatorname{HbSS}(P=$ 0.569 ) genotypes, these differences were not statistically significant. However, the WBC count was statistically significant across the genotypes $(P=0.004)$. Lymphocyte 


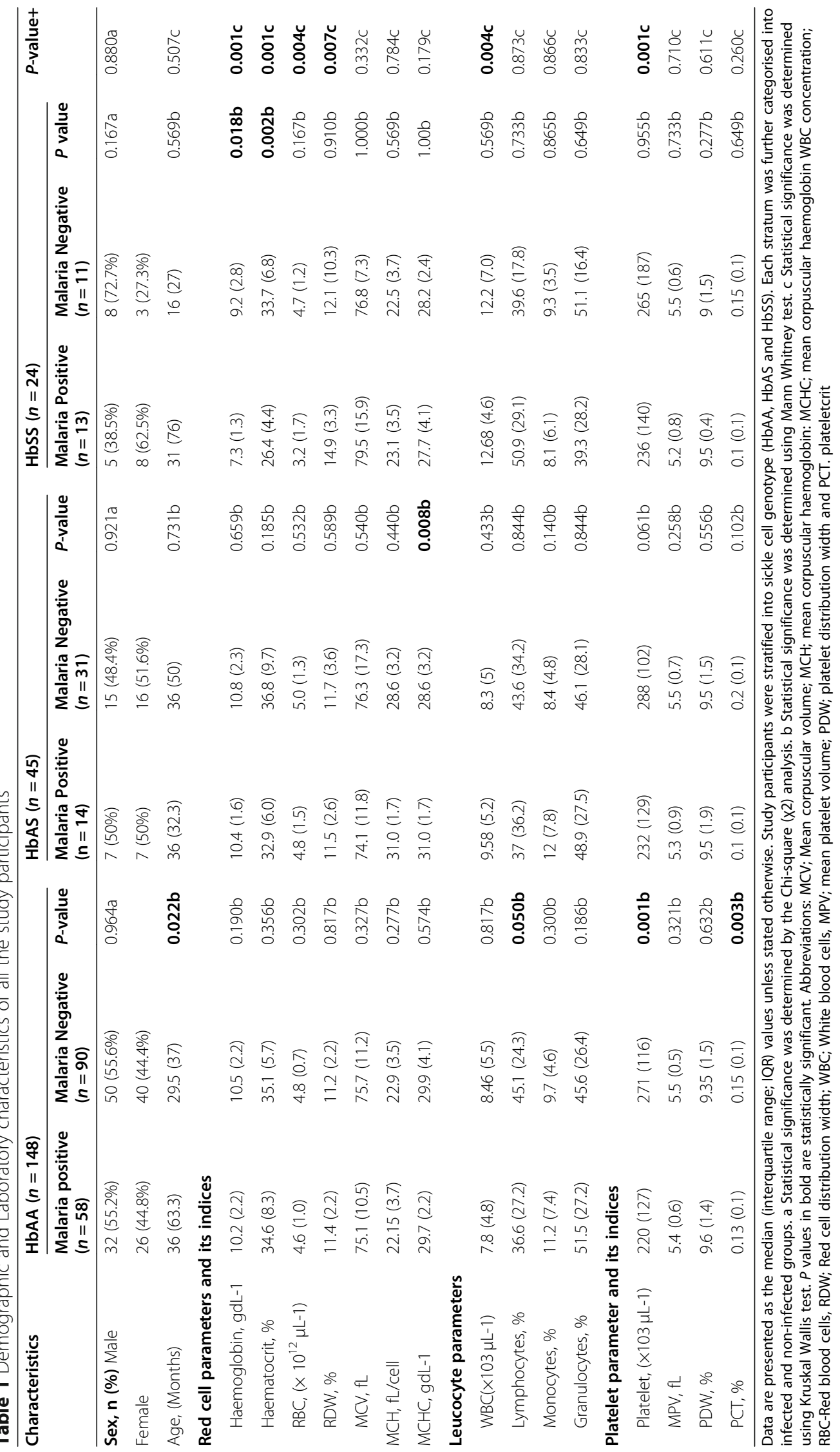


was lower in the infected group relative to non-infected group within the HbAA genotype [median (IQR); 36.6 (27.2), and [median (IQR); 45 (224.3), $P=0.05$ ], respectively. Both monocytes $(P=0.866)$ and granulocytes $(P=$ $0.833)$ were comparable within the genotypes. Among the platelet parameters and its indices, platelet count was more exceptional in its comparability within the HbAA genotype. Infected group had lower platelet count relative to non-infected group [median (IQR); 220 (127), and [median (IQR); 271 (116), $P=0.001]$, respectively. This significance was equally simulated in the comparison across the three genotypes $(P=0.001)$. The MPV $(P=0.710)$ and PDW $(P=0.611)$ were comparable across the genotypes. The PCT was only statistically significant within HbAA genotype with [median (IQR); $0.13(0.1)$, and [median (IQR); 0.15 (0.1), $P=0.003$ ] for infected and non-infected groups, respectively. All the determined demographic and laboratory characteristics are summarized in Table 1.

\section{Association between haematological parameters and sickle cell genotypes in $P$. falciparum infected children} Considering the distribution of haematological parameters in the three stratified study groups, their association with sickle cell genotypes in P. falciparum infected children were modelled using logistic regression model while controlling for the infection status. Infection status was controlled for since sickle gene has an influence of the haematological parameters regardless of infection, however, malaria infection can further worsen the levels of these parameters. Using the homozygous wild-type genotypes (HbAA) as the reference group, results revealed no association between $\mathrm{HbAS}$ and haemoglobin $[\mathrm{OR}=1.098,95 \% \mathrm{CI}=0.555-2.171, P=0.789]$, haematocrit $[\mathrm{OR}=1.140,95 \% \mathrm{CI}=0.568-2.287, P=0.713], \mathrm{RBC}$ count $[\mathrm{OR}=0.706,95 \% \mathrm{CI}=0.235-2.123, P=0.100]$ and RDW [OR $=0.093,95 \% \mathrm{CI}=0.514-2.323, P=0.818$ ]. However, there was a significant association between HbSS and haemoglobin $[\mathrm{OR}=0.310,95 \% \mathrm{CI}=0.101-$ $0.956, P=0.041]$, haematocrit $[\mathrm{OR}=0.318,95 \% \mathrm{CI}=$ $0.128-0.793, P=0.014], \mathrm{RBC}$ count $[\mathrm{OR}=0.124,95 \%$ $\mathrm{CI}=0.045-0.337, P=0.001]$ and RDW $[\mathrm{OR}=2.993,95 \%$ $\mathrm{CI}=0.952-9.409, \quad P=0.061] \quad$ (See Table 2). Reduced MCV (microcytosis) was neither associated with HbAS $[\mathrm{OR}=1.193,95 \% \mathrm{CI}=0.609-2.334, P=0.606]$ nor HbSS $[\mathrm{OR}=2.094,95 \% \mathrm{CI}=0.854-5.137, P=0.106]$. Furthermore, increased MCV (macrocytosis) [OR $=1.058,95 \%$ $\mathrm{CI}=0.107-10.452, P=0.962]$ was not associated with $\mathrm{HbAS}$, however, association between $\mathrm{HbSS}$ and increased MCV did not run in the regression model. Additional analyses revealed that reduced $\mathrm{MCH}$ did not show any association with $\mathrm{HbAS}[\mathrm{OR}=0.763,95 \% \mathrm{CI}=$ $0.263-2.219, P=0.620]$. Moreover, reduced $\mathrm{MCH}$ did not show any association with $\mathrm{HbSS}[\mathrm{OR}=0.507,95 \%$
$\mathrm{CI}=0.110-2.340, P=0.383]$ while reduced $\mathrm{MCHC}$ did not reveal association with $\mathrm{HbAS}[\mathrm{OR}=0.819,95 \% \mathrm{CI}=$ 0.373-1.798, $P=0.619$ ]. However, reduced $\mathrm{MCHC}$ showed association $\mathrm{HbSS}[\mathrm{OR}=0.325,95 \% \mathrm{CI}=0.118$ $0.892, P=0.029$ ]. Total reduction in white blood cell count (leucocytopaenia) was not associated with $\mathrm{HbAS}$ $[\mathrm{OR}=0.131,95 \% \mathrm{CI}=0.011-1.528, P=0.105]$. However, leucocytosis showed increased association with $\mathrm{HbSS}$ $[\mathrm{OR}=9.283,95 \% \mathrm{CI}=3.167-27.210, P=0.001]$. Both elevated and reduced lymphocyte and granulocyte counts did not reveal association with either HbAS or HbSS in $P$. falciparum infected children. However, increased monocyte count (monocytosis) revealed association with $\mathrm{HbSS}[\mathrm{OR}=0.319,95 \% \mathrm{CI}=0.123-0.830, P=0.019]$.

With regard to platelet parameters and its indices, reduced platelet count (thrombocytopenia) did not show association with $\mathrm{HbAS}[\mathrm{OR}=1.746,95 \% \mathrm{CI}=0.330$ 9.243, $P=0.512]$. Furthermore, increased thrombocyte count (thrombocytosis) equally showed no association with $\mathrm{HbAS}[\mathrm{OR}=0.984,95 \% \mathrm{CI}=0.463-2.095, \quad P=$ 0.968]. Unfortunately, the model could not determine association of either thrombocytopenia or thrombocytosis with HbSS genotype in children infected with malaria. Micro-platelet was defined as a platelet with reduced mean platelet volume (MPV) to below $6 \mathrm{fL}$ [36]. Micro-platelet was associated with $\mathrm{HbAS}[\mathrm{OR}=3.269$, $95 \% \mathrm{CI}=1.291-8.276, P=0.012]$ but was no associated with $\mathrm{HbSS} \quad[\mathrm{OR}=4.781,95 \% \mathrm{CI}=0.355-6.470, \quad P=$ 0.238]. Furthermore, PDW did not show any association with $\mathrm{HbAS} \quad[\mathrm{OR}=0.932,95 \% \mathrm{CI}=0.286-3.035, \quad P=$ 0.907], however, its association with HbSS was undetermined. Finally, PCT did not show any association with $\mathrm{HbAS}[\mathrm{OR}=1.017,95 \% \mathrm{CI}=0.304-3.405, P=0.978]$ and with $\mathrm{HbSS} \quad[\mathrm{OR}=0.552,95 \% \mathrm{CI}=0.220-13.900, \quad P=$ 0.718] (See Table 2).

\section{Association between sickle cell genotype and Plasmodium falciparum infection}

With HbAA as the reference group, bivariate logistic regression analysis was modelled to determine association between sickle cell genotypes and $P$. falciparum infection. Results revealed that both HbAS [OR $=0.701,95 \%$ $\mathrm{CI}=0.344-1.429, P=0.328]$ and $\mathrm{HbSS}[\mathrm{OR}=1.834,95 \%$ $\mathrm{CI}=0.774-4.369, P=0.171]$, was not associated with $P$. falciparum infection (See Table 3).

\section{Discussion}

Variations in blood cell counts and its parameters occur in congenital haematological disorders of which sickle cell disease is a prime example. Furthermore, such alterations have also been common in malaria, and reported to be more pronounced in $P$. falciparum infection for the HbAA genotype [21,38]. However, the magnitude of such alterations differ depending on genetic, and 
Table 2 Association between haematological parameters and sickle cell genotypes

\begin{tabular}{|c|c|c|c|c|c|}
\hline Parameter & Dichotomised haematological outcome & Sickle cell genotype & OR & $95 \% \mathrm{Cl}$ & $P$-value \\
\hline \multirow[t]{2}{*}{ Haemoglobin } & Anaemia (Haemoglobin < 10 gdL-1) & $\mathrm{HbAS}$ & 1.098 & $0.555-2.171$ & 0.789 \\
\hline & & $\mathrm{HbSS}$ & 0.310 & $0.101-0.956$ & 0.041 \\
\hline \multirow[t]{2}{*}{ Haematocrit } & (Haematocrit < 33\%) & $\mathrm{HbAS}$ & 1.140 & $0.568-2.287$ & 0.713 \\
\hline & & HbSS & 0.318 & $0.128-0.793$ & 0.014 \\
\hline \multirow[t]{2}{*}{ RBC count } & Erythrocytopaenia (RBC count $<3.8 \times 10^{12} \mu \mathrm{L}-1$ ) & $\mathrm{HbAS}$ & 0.706 & $0.235-2.123$ & 0.100 \\
\hline & & HbSS & 0.124 & $0.045-0.337$ & 0.001 \\
\hline \multirow[t]{2}{*}{ RDW } & $(<12 \%)$ & $\mathrm{HbAS}$ & 0.093 & $0.514-2.323$ & 0.818 \\
\hline & & HbSS & 2.993 & $0.952-9.409$ & 0.061 \\
\hline \multirow[t]{4}{*}{ MCV } & Microcytosis (MCV < $76 \mathrm{fL}$ ) & $\mathrm{HbAS}$ & 1.193 & $0.609-2.334$ & 0.606 \\
\hline & & $\mathrm{HbSS}$ & 2.094 & $0.854-5.137$ & 0.106 \\
\hline & Macrocytosis (MCV > $96 \mathrm{fL})$ & $\mathrm{HbAS}$ & 1.058 & $0.107-10.452$ & 0.962 \\
\hline & & $\mathrm{HbSS}$ & $X X X$ & $X X X$ & $X X X$ \\
\hline \multirow[t]{2}{*}{$\mathrm{MCH}$} & $(<25 \mathrm{Pg})$ & $\mathrm{HbAS}$ & 0.763 & $0.263-2.219$ & 0.620 \\
\hline & & $\mathrm{HbSS}$ & 0.507 & $0.110-2.340$ & 0.384 \\
\hline \multirow[t]{2}{*}{$\mathrm{MCHC}$} & $(<28$ gdL-1) & $\mathrm{HbAS}$ & 0.819 & $0.373-1.798$ & 0.619 \\
\hline & & $\mathrm{HbSS}$ & 0.325 & $0.118-0.892$ & 0.029 \\
\hline \multirow[t]{4}{*}{ WBC } & Leucocytopaenia (WBC < 4× $103 \mu \mathrm{L}-1)$ & $\mathrm{HbAS}$ & 0.131 & $0.011-1.528$ & 0.105 \\
\hline & & $\mathrm{HbSS}$ & $X X X$ & $X X X$ & $X X X$ \\
\hline & Leucocytosis (WBC > 10× $103 \mu \mathrm{L}-1)$ & $\mathrm{HbAS}$ & 1.485 & $0.692-3.185$ & 0.310 \\
\hline & & $\mathrm{HbSS}$ & 9.283 & $3.167-27.210$ & 0.001 \\
\hline \multirow[t]{4}{*}{ Lymphocytes } & Lymphoctopenia (Lymphocytes < 20\%) & $\mathrm{HbAS}$ & 0.625 & $0.265-1.473$ & 0.283 \\
\hline & & HbSS & 3.014 & $0.646-14.069$ & 0.160 \\
\hline & Lymphocytosis (Lymphocytes > 40\%) & $\mathrm{HbAS}$ & 0.607 & $0.180-2.052$ & 0.422 \\
\hline & & HbSS & 0.636 & $0.101-4.018$ & 0.630 \\
\hline \multirow[t]{2}{*}{ Monocytes } & Monocytosis (Monocytes, > 10\%) & $\mathrm{HbAS}$ & 0.800 & $0.406-1.574$ & 0.518 \\
\hline & & $\mathrm{HbSS}$ & 0.319 & $0.123-0.830$ & 0.019 \\
\hline \multirow[t]{4}{*}{ Granulocytes } & Granulocytopaenia (Granulocytes, <30\%) & $\mathrm{HbAS}$ & 0.446 & $0.182-1.089$ & 0.760 \\
\hline & & HbSS & 2.201 & $0.459-10.547$ & 0.324 \\
\hline & Granulocytosis (Granulocytes, > 70\%) & $\mathrm{HbAS}$ & 0.941 & $0.354-2.503$ & 0.903 \\
\hline & & HbSS & 0.538 & $0.117-2.473$ & 0.426 \\
\hline \multirow[t]{4}{*}{ Platelets } & Thrombocytopaenia (Platelet count $<150 \times 103 \mu \mathrm{L}-1$ ) & $\mathrm{HbAS}$ & 1.746 & $0.330-9.243$ & 0.512 \\
\hline & & HbSS & $X X X$ & $X X X$ & $X X X$ \\
\hline & Thrombocytosis (Platelet count $>300 \times 103 \mu \mathrm{L}-1$ ) & $\mathrm{HbAS}$ & 0.984 & $0.463-2.095$ & 0.968 \\
\hline & & $\mathrm{HbSS}$ & $X X X$ & $X X X$ & $X X X$ \\
\hline \multirow[t]{3}{*}{ MPV } & Micro platelets (Platelets < $6 \mathrm{fL}$ ) Megathrombocytes (platelets> $12.3 \mathrm{fL}$ ) & $\mathrm{HbAS}$ & 3.269 & $1.291-8.276$ & 0.012 \\
\hline & & HbSS & 4.781 & $0.355-6.470$ & 0.238 \\
\hline & & NA & NA & NA & NA \\
\hline \multirow[t]{2}{*}{ PDW } & $(\mathrm{PDW},<6 \%)$ & $\mathrm{HbAS}$ & 0.932 & $0.286-3.035$ & 0.907 \\
\hline & & $\mathrm{HbSS}$ & $X X X$ & $X X X$ & $X X X$ \\
\hline \multirow[t]{2}{*}{ PCT } & $(\mathrm{PCT},<0.22 \%)$ & $\mathrm{HbAS}$ & 1.017 & $0.304-3.405$ & 0.978 \\
\hline & & $\mathrm{HbSS}$ & 0.552 & $0.220-13.900$ & 0.718 \\
\hline
\end{tabular}

Children $(n=217)$ with acute febrile condition were categorized on the basis of sickle cell genotype (HbAA and HbSS). Odds ratios (OR) and $95 \%$ confidence intervals $(\mathrm{Cl})$ were determined using multivariate logistic regression analysis controlling for infection status. $P$-values in bold were statistically significant at $P \leq$ 0.05. XXX; did to run in the regression model. NA; not applicable. The reference groups in the logistic regression analysis were the homozygous wild-type genotypes (HbAA) 
Table 3 Association between Sickle cell genotype and $P$. falciparum infection

\begin{tabular}{llll}
\hline $\begin{array}{l}\text { Sickle cell } \\
\text { genotypes }\end{array}$ & \multicolumn{3}{l}{$\boldsymbol{P}$. falciparum } \\
\cline { 2 - 4 } & OR & $\mathbf{9 5 \%} \mathbf{C l}$ & $\boldsymbol{P}$-value \\
\hline HbAA, $(n=148)$ & Ref & - & - \\
HbAS, $(n=45)$ & 0.701 & $0.344-1.429$ & 0.328 \\
HbSS, $(n=24)$ & 0.1834 & $0.774-4.369$ & 0.171
\end{tabular}

Children with acute febrile condition $(n=217)$ were grouped based on the haemoglobin genotype. Odds ratios (OR) and $95 \%$ confidence intervals (Cl) were determined across genotypes using bivariate logistic regression model controlling for age, sex. $P$-values in bold was statistically significant at $P \leq 0.05$. The reference groups in the regression analysis were the homozygous wildtype genotypes (HbAA)

epigenetic factors [22]. Our study provides a unique approach by not only looking at the comparisons of the haematological parameters in sickle cell genotypes in $P$. falciparum infection but also determines the association of these parameters to sickle cell gene in the infection. A few studies have been carried out in African countries where malaria is holoendemic with varied demonstrations on the protective effect of sickle cell gene (HbAS and $\mathrm{HbSS}$ ) of asymptomatic and symptomatic P. falciparum infection of variable severity [14, 20, 22, 23]. None of the above studies have specifically described haematological differences on the basis of sickle cell genotypes in children presenting with steady state of $P$. falciparum malaria apart from Prohit et al. [24] and McAuley et al. [39]. However, Prohit et al used patients aged 15-34 years and narrowed it down to severe $P$. falciparum malaria as opposed to children with non-severe malaria in the current study. On the other hand, McAuley and colleagues [39] failed to determine a true association between the risks of severe malaria in HbSS due to low sample size (only 5 cases of HbSS were studied).

In our study, the prevalence of malaria was lower in HbAS (31.1\%), in comparison to HbAA (39.2\%). Likewise, numerous studies have demonstrated a lower prevalence of malaria among children with HbAS relative to those with HbAA [14, 40, 41]. Our finding is consistent with that of Makani et al. among other studies in Africa where sickle cell disease is prevalent and malaria is holoendemic [41]. Reduced prevalence to P. falciparum malaria in the HbAS genotype group could be attributed to the already postulated mechanisms which confer protective effect of haemoglobin $\mathrm{S}$ against $P$. falciparum malaria. They include [1] reduced ability of parasites to grow (reduced intra-erythrocyte growth of parasites $[2,42]$ accelerated sickling of infected RBCs and ultimate clearance $[3,43]$ increased humoral and cell-mediated immune response [44] and [4] aberrant cytoskeleton within erythrocytes which contains $\mathrm{HbS}$ and $\mathrm{HbC}$ results in defective trafficking and altered delay of parasite encoded protein-Plasmodium falciparum membrane protein 1 (PfEMP-1) on the surface of parasitized erythrocytes [45]. In addition, it has been demonstrated that tolerance phenomenon of host to $P$. falciparum infection resulting from $\mathrm{HbS}$-induced chronic production of haeme-oxygenase- 1 and carbon monoxide [46] and that [5] translocation of sickle cell erythrocyte microRNAs into falciparum inhibits parasite translocation [20]. Nonetheless, individuals of homozygous sickle cell genotype (HbSS) undergo severe clinical effects of malaria [47-49]. Increased MCV in children with $\mathrm{HbSS}$ as opposed to those with HbAA and HbAS shown in the current study could be attributed to the fact that children carrying the HbSS genotype have chronic haemolysis hence stimulating consistent haemopoiesis and haemopoietic processes geared towards compensatory responses and that young erythrocytes have higher MCV [37]. However, this hypothesis needs further explorations.

Leucocytosis has previously been reported in children infected with malaria $[21,50]$ and in children with sickle cell disease $[30,51]$ and both findings attribute this to active erythropoiesis. Nevertheless, thrombocytosis revealed in the current study may be explained by background haemolytic anaemia and auto-splenectomy [51].

To determine the associations of haematological parameters and sickle cell genotypes, anaemia was defined as a condition where the haemoglobin level was below the lower reference $(<10 \mathrm{gdL}-1)$ and $\mathrm{RBC}$ count $(<$ $\left.3.8 \times 10^{12} \mu \mathrm{L}-1\right)$ with regard to age, sex and altitude [36, 52, 53]. Association between reduced haemoglobin levels, reduced haematocrit and reduced RBC count with HbSS could be due to haemolytic mechanism and increased removal of parasitized red blood cells through erythrophagocytosis [38, 54-56]. Another factor that might lead to low levels of these haemoglobin parameters in children with HbSS is abnormally high tumour necrosis factor (TNF) in P. falciparum infection [56]. However this was not assessed in the context of the current study. In our study, carriage of HbSS was associated with reduced $\mathrm{MCHC}$. This means that children with the carriage of HbSS and are infected with P. falciparum were less likely to have reduced $\mathrm{MCHC}$. The mean corpuscular haemoglobin concentration $(\mathrm{MCHC})$ was defined as a measure of the concentration of haemoglobin in a given volume of packed red blood cell with a reference range of 28-36 gdL-1 [53]. Reduced association of reduced MCHC with $\mathrm{HbSS}$ was not surprising due to the fact that $\mathrm{MCHC}$ is derived from haemoglobin concentration and haematocrit which are primary red cell measurement and any factor affecting haemoglobin and haematocrit in either sickle cell or malaria would definitely affect $\mathrm{MCHC}$ [25]. Leucocytosis was defined as the increase in the number of circulating total white blood cells to above $11 \times 103 \mu \mathrm{L}-1$ of blood [36, 52]. Children of HbSS genotype with $P$. falciparum were nine 
times more likely to have leucocytosis. Increased association of leucocytosis with carriage of HbSS in the current study may still be attributed to increased erythropoiesis and consistent haemolysis [37] but more exploration on this is still wanting to establish weather carriage of $\mathrm{HbSS}$ is associated with left shift, right shift or mixed shifts leucocytosis. Furthermore, previous studies attributed leucocytosis to the pathogenesis of sickle cell crisis [27]. Monocytosis was defined as a haematological condition in which the monocyte count in peripheral blood if above $10 \%$ of the total leucocyte count [36]. The current study has additionally shown that carriage of $\mathrm{HbSS}$ is associated with reduced monocytosis. This finding has further reinforced that of Wongtong and colleagues [57] that investigated the association of absolute monocyte count with laboratory variables in patients with sickle cell disease. In this case, inflammatory state in carriage of HbSS may contribute to monocytosis [57]. Moreover, monocytes are activated in sickle cell disease with expression of tumour necrosis factor alpha (TNF- $\alpha$ ) and interleukin-1 beta (IL-1 $\beta$ ) as well as adhesion of molecule ligand, CD11b [58-60]. Association of reduced MPV with HbAS in children infected with malaria in the current study was quite amazing. Although, carriage of $\mathrm{HbAS}$ gene has been reported to offer protection against malaria morbidity and mortality [40, 61], a high or normal platelet count alongside micro-platelets often signifies inflammation, infection or cancer [62]. We the therefore attribute increase of these microplatelets to malaria infection in the current study.

Numerous studies have demonstrated protective effect of $\mathrm{HbSS}$ from $P$. falciparum infection compared to HbAS but results in higher morbidity and mortality once the infection occur $[14,61,63,64]$. However, we did not find any significant association between both HbAS and HbSS with P. falciparum infection. A study in Uganda involving both children and adults revealed that both HbAS and HbSS were associated with reduced nonsevere malaria outcomes [28]. The difference in our results in reference to other studies could be attributed to the fact that we only used children (1-192 months) stratified into infected and non-infected groups. This is the first study in East Africa to elucidate the association between selected haematological parameters and haemoglobin genotypes in children with P. falciparum. However, our study is limited to the fact that we did not investigate the level of parasitaemia and other haemoglobinopathies such as Glucose-6-phosphate dehydrogenase (G6PD), and alpha thalassaemia which is known to have epistasis effects on sickle cell gene with respect to $P$. falciparum malaria [65]. A longitudinal study with a larger cohort of participants may be valuable in extrapolating the knowledge gap for determination and understanding of such associations.

\section{Conclusion}

HbSS genotype is associated with low haemoglobin, haematocrit, $\mathrm{RBC}, \mathrm{MCHC}, \mathrm{WBC}$ and monocytes. In addition we show that, carriage of $\mathrm{HbAS}$ is associated with lower MPV in children infected with malaria. HbSS genotype is association with low haemoglobin, haematocrit, $\mathrm{RBC}, \mathrm{MCHC}$ and moncytopenia. However, it is associated with increased leucocytosis in children with $P$. falciparum malaria. Moreover, our study revealed that carriage of HbAS is associated with lower MPV in children infected with malaria. Results from this study can help in the differential diagnosis of malaria infection in HbSS genotype based on haematological parameters in resource limited setting where sickle cell genotyping remains a challenge. Therefore, for proper management of $P$. falciparum malaria, sickle cell genotyping should be considered to guide on the administration of antimalarial prophylaxis to HbSS patients.

\section{Supplementary Information}

The online version contains supplementary material available at https://doi. org/10.1186/s12879-020-05625-z.

\section{Additional file 1.}

Additional file 2.

\section{Abbreviations}

$\mu$ g: Microgram; $\mu$ l: Microlitre; CBD: Central Business District; EDTA: Ethylene diamine tetra-acetic acid; g/dl: Grams per decilitre; Hb: Haemoglobin; HbAA: Genotype of the normal haemoglobin; HbAS: Genotype in sickle cell trait; HbSS: Genotype in sickle cell anaemia; HIV: Human immunodeficiency virus; JOOTRH: Jaramogi Oginga Odinga Teaching and Referral Hospital; MCH: Mean cell haemoglobin; MCHC: Mean cell haemoglobin concentration; MCV : Mean cell volume; Mls: Millilitres; OPD: Outpatient Department; PBF: Peripheral blood film examination; PCR: Polymerase Chain Reaction; Pg: Picogram; RBC: Red blood cells; RDW: Red cell distribution width; RPM: Revolutions per minute; rs: Reference SNP number; SCA: Sickle cell anaemia; SCD: Sickle cell disease; SCT : Sickle cell trait; SPSS: Statistical package for social sciences; WHO: World Health Organisation

\section{Acknowledgements}

We are grateful to the Chief Administrator and the Ethical Review Committee of Jaramogi Oginga Odinga Teaching and Referral Hospital. Authors are grateful to clinical staff of JOOTRH. We also express our sincere gratitude to children, their guardians as well as adults who participated in this study. In a special way, we are grateful to the laboratory staff for their good cooperation and hard work during the collection and analysis of clinical specimens.

\section{Authors' contributions}

PK, WO, JG and CO designed the study and were involved in all aspects of the study. WO, JK and CO supervised the study. PK and CO performed data analysis and drafted the manuscript. WO, EM and JG reviewed the manuscript for intellectual inputs. All authors reviewed final manuscript and approved it for submission.

\section{Funding}

Not applicable.

\section{Availability of data and materials}

The datasets generated and/or analysed during the current study are not publicly available due to compliance with ethical reviewer's guidelines but are obtainable from the corresponding author on reasonable request. 


\section{Ethics approval and consent to participate}

The study was approved by the Jaramogi Oginga Odinga Teaching and Referral Hospital (JOOTRH) Ethical Review committee. All study participants and or guardians for minors provided informed written consent to participate in the study.

\section{Consent for publication}

Not applicable.

\section{Competing interests}

The authors have declared no competing interest.

\section{Author details}

${ }^{1}$ Department of Biomedical Science and Technology, School of Pub;ic Health and Community Development, Maseno University, Maseno, Kenya. ${ }^{2}$ Department of Medical Laboratory Sciences, School of Medicine, Kisii University, P.O. Box 408-40200, Kisii, Kenya. ${ }^{3}$ Department of Paediatrics and Child Health, School of Medicine, Maseno University, Private Bag, Maseno, Kenya. ${ }^{4}$ School of Clinical Medicine, Mount Kenya University, Gen Kago Rd, P.O. Box 342 01000, Thika, Kenya. ${ }^{5}$ Department of Clinical Medicine, School of Health Sciences, Kirinyaga University, P.O Box 143-10300, Kerugoya, Kenya.

Received: 23 July 2020 Accepted: 17 November 2020

Published online: 25 November 2020

\section{References}

1. Serjeant GR, Vichinsky E. Variability of homozygous sickle cell disease: the role of alpha and beta globin chain variation and other factors. Blood Cells Mol Dis. 2018;70:66-77.

2. Steinberg MH. Sickle cell anemia, the first molecular disease: overview of molecular etiology, pathophysiology, and therapeutic approaches. ScientificWorldJournal. 2008:8:1295-324.

3. Chiang EY, Frenette PS. Sickle cell vaso-occlusion. Hematol Oncol Clin North Am. 2005;19(5):771-84 v.

4. Bunn HF. Subunit assembly of hemoglobin: an important determinant of hematologic phenotype. Blood. 1987;69(1):1-6.

5. Murayama M. Structure of sickle cell hemoglobin and molecular mechanism of the sickling phenomenon. Clin Chem. 1967;13(7):578-88.

6. Ekvall H, Arese P, Turrini F, Ayi K, Mannu F, Premji Z, et al. Acute haemolysis in childhood falciparum malaria. Trans R Soc Trop Med Hyg. 2001;95(6):611-7.

7. Selvam R, Baskaran G. Hematological impairments in recurrent Plasmodium vivax infected patients. Jpn J Med Sci Biol. 1996;49(4):151-65.

8. Waitumbi JN, Opollo MO, Muga RO, Misore AO, Stoute JA. Red cell surface changes and erythrophagocytosis in children with severe plasmodium falciparum anemia. Blood. 2000;95(4):1481-6.

9. Piel FB, Patil AP, Howes RE, Nyangiri OA, Gething PW, Williams TN, et al. Global distribution of the sickle cell gene and geographical confirmation of the malaria hypothesis. Nat Commun. 2010;1:104.

10. Kai OK, Roberts DJ. The pathophysiology of malarial anaemia: where have all the red cells gone? BMC Med. 2008;6:24.

11. (NIH) NloH. Understanding malaria: fighting an ancient scourge. US Department of Health and Human Services. Bethesda, MD. 2007.

12. Kapesa A, Kweka EJ, Atieli H, Afrane YA, Kamugisha E, Lee M-C, et al. The current malaria morbidity and mortality in different transmission settings in Western Kenya. PLoS One. 2018;13(8):e0202031.

13. Otieno W, Estambale BBA, Odera MM, OSM, Aluoch JR, Stoute JA. Sickle cell trait (HbAS) is associated with increased expression of erythrocyte complement regulatory proteins CR1 and CD55 levels in children. Int J Trop Dis Health. 2013;3(2):133-47.

14. Otieno W, Estambale BBA, Aluoch JR, Gondi SMO, Stoute JA. Association between sickle cell trait and low density Parasitaemia in a P. falciparum malaria Holoendemic region of Western Kenya. Int J Trop Dis Health. 2012; 2(4):231-40.

15. Otoikhan CS, Osakwe AA, Utieyin MC, Igue UB. Malaria resistance and Sickle cell trait. Int J Life Sci Biomed Pharma Res. 2014;3(3):16.

16. Karlsson EK, Kwiatkowski DP, Sabeti PC. Natural selection and infectious disease in human populations. Nat Rev Genet. 2014;15(6):379-93.

17. Kwiatkowski DP. How malaria has affected the human genome and what human genetics can teach us about malaria. Am J Hum Genet. 2005;77(2): 171-92.
18. Olatunji PO. Malaria and the sickle gene: polymorphism balance in favour of eradication. Ann Health Res. 2018;4(2):88-96.

19. Beutler E. G6PD deficiency. Blood. 1994;84(11):3613-36.

20. Gong L, Maiteki-Sebuguzi C, Rosenthal PJ, Hubbard AE, Drakeley CJ, Dorsey $\mathrm{G}$, et al. Evidence for both innate and acquired mechanisms of protection from Plasmodium falciparum in children with sickle cell trait. Blood. 2012; 119(16):3808-14.

21. Maina RN, Walsh D, Gaddy C, Hongo G, Waitumbi J, Otieno L, et al. Impact of Plasmodium falciparum infection on haematological parameters in children living in Western Kenya. Malar J. 2010;9 Suppl 3:S4.

22. Albiti AH, Nsiah K. Comparative haematological parameters of HbAA and $\mathrm{HbAS}$ genotype children infected with Plasmodium falciparum malaria in Yemen. Hematology. 2014;19(3):169-74.

23. Erhabor O, Mohammad HJ, Onuigue FU, Abdulrahaman Y, Ezimah AC. Anaemia and thrombocytopenia among malaria parasitized children in Sokoto, North Western Nigeria. J Hematol Transfusion. 2014;2(2):1020.

24. Purohit P, Mohanty PK, Patel S, Das P, Panigrahi J, Das K. Comparative study of clinical presentation and hematological indices in hospitalized sickle cell patients with severe Plasmodium falciparum malaria. J Infect Public Health. 2018;11(3):321-5.

25. Hoffbrand AV, Moss PAH, Pettit JE. Essential Haematology. vol. 5. Malden, Mass: Oxford: Blackwell Publishing; 2006. p. 249.

26. Obimba K, Eziuzor SC, Ozougwu JC, et al. Biochemical and hematological diagnostic indices of homozygous sickle cell anemia patients in the steady state. Int J Med Med Sci. 2015;5(11):299-306.

27. Wonkam A, Mnika K, Ngo Bitoungui VJ, Chetcha Chemegni B, Chimusa ER, Dandara C, et al. Clinical and genetic factors are associated with pain and hospitalisation rates in sickle cell anaemia in Cameroon. Br J Haematol. 2018;180(1):134-46.

28. Kakande E, Greenhouse B, Bajunirwe F, Drakeley C, Nankabirwa JI, Walakira $A$, et al. Associations between red blood cell variants and malaria among children and adults from three areas of Uganda: a prospective cohort study. Malar J. 2020;19(1):21.

29. Eleonore NLE, Cumber SN, Charlotte EE, Lucas EE, Edgar MML, Nkfusai CN, et al. Malaria in patients with sickle cell anaemia: burden, risk factors and outcome at the Laquintinie hospital. Cameroon BMC Infect Dis. 2020;20(1):40.

30. Fasola FA, Adekanmi AJ. Haematological profile and blood transfusion pattern of patients with sickle cell Anaemia vary with spleen size. Ann lb Postgrad Med. 2019;17(1):30-8.

31. KNBS. Kenya Population and Housing Census (10 Per Cent sample, every 10th household), Population and Housing Census. 2019.

32. KNBS. The 2015 Kenya Malaria Indicator Survey. National Malaria Control Programme of the Ministry of Health, 19982, Kenyatta National Hospital, Nairobi 00202, Kenya; telephone: +254 20271 6934/5; fax: +254 20271 6935; e-mail: headdomc@domckenyaorke; Internet: wwwnmcporke. 2016.

33. Okiro EA, Alegana VA, Noor AM, Snow RW. Changing malaria intervention coverage, transmission and hospitalization in Kenya. Malar J. 2010;9:285.

34. Cochran WG. Sampling Techniques 2nd Ed. New York: John Wiley and Sons; 1963.

35. Beier JC, Oster CN, Onyango FK, Bales JD, Sherwood JA, Perkins PV, et al. Plasmodium falciparum incidence relative to entomologic inoculation rates at a site proposed for testing malaria vaccines in western Kenya. Am J Trop Med Hyg. 1994;50(5):529-36.

36. Palmer L, Briggs $C$, McFadden S, Zini G, Burthem J, Rozenberg G, et al. ICSH recommendations for the standardization of nomenclature and grading of peripheral blood cell morphological features. Int J Lab Hematol. 2015;37(3): 287-303.

37. Omoti CE. Haematological values in sickle cell anaemia in steady state and during vaso-occlusive crisis in Benin City, Nigeria. Ann Afr Med. 2005;4:62-7.

38. Mboya PK, Sumba PO, Oluoch JN, Abdallah FK, Mala AO. Correlation between thrombocytopenia and Anaemia in Plasmodium falciparum malaria among patients in Kisumu County-Western Kenya. Afr J Health Sci. 2016;29(2):76-88.

39. McAuley CF, Webb C, Makani J, Macharia A, Uyoga S, Opi DH, et al. High mortality from Plasmodium falciparum malaria in children living with sickle cell anemia on the coast of Kenya. Blood. 2010;116(10):1663-8.

40. Ferreira A, Marguti I, Bechmann I, Jeney V, Chora A, Palha NR, et al. Sickle hemoglobin confers tolerance to Plasmodium infection. Cell. 2011;145(3): 398-409.

41. Makani J, Komba AN, Cox SE, Oruo J, Mwamtemi K, Kitundu J, et al. Malaria in patients with sickle cell anemia: burden, risk factors, and outcome at the outpatient clinic and during hospitalization. Blood. 2010;115(2):215-20. 
42. Pasvol G, Weatherall DJ, Wilson RJ. Cellular mechanism for the protective effect of haemoglobin S against P. falciparum malaria. Nature. 1978; 274(5672):701-3.

43. Luzzatto L, Nwachuku-Jarrett ES, Reddy S. Increased sickling of parasitized erythrocytes as mechanism of resistance against malaria in the sickle trait. Lancet. 1970;1:319-21.

44. Verra F, Simpore J, Warimwe GM, Tetteh KK, Howard T, Osier FH, et al. Haemoglobin $\mathrm{C}$ and $\mathrm{S}$ role in acquired immunity against Plasmodium falciparum malaria. PLoS One. 2007;2(10):e978.

45. Cyrklaff M, Sanchez CP, Kilian N, Bisseye C, Simpore J, Frischknecht F, et al. Hemoglobins $S$ and $C$ interfere with actin remodeling in Plasmodium falciparum-infected erythrocytes. Science. 2011;334(6060):1283-6.

46. Ferreira A, Marguti I, Bechmann I, Jeney V, Chora A, NR P. Sickle cell haemoglobin confers tolerance to plasmodium falciparum infection. Cell. 2011(145):398-409.

47. Aluoch JR. The presence of sickle cells in the peripheral blood film. Specificity and sensitivity of diagnosis of homozygous sickle cell disease in Kenya. Trop Geogr Med. 1995;47(2):89-91.

48. Aluoch JR. Higher resistance to Plasmodium falciparum infection in patients with homozygous sickle cell disease in western Kenya. Tropical Med Int Health. 1997;2(6):568-71.

49. Nagel RL, Fleming AF. Genetic epidemiology of the beta s gene. Baillieres Clin Haematol. 1992;5(2):331-65.

50. Davenport GC, Ouma C, Hittner JB, Were T, Ouma Y, Ong'echa JM, et al. Hematological predictors of increased severe anemia in Kenyan children coinfected with Plasmodium falciparum and HIV-1. Am J Hematol. 2010; 85(4):227-33.

51. Akinbami A, Dosunmu A, Adediran A, Oshinaike O, Adebola P, Arogundade O. Haematological values in homozygous sickle cell disease in steady state and haemoglobin phenotypes AA controls in Lagos, Nigeria. BMC Res Notes. 2012:5:396.

52. Gitaka J, Ogwang C, Ngari M, Akoo P, Olotu A, Kerubo C, et al. Clinical laboratory reference values amongst children aged 4 weeks to 17 months in Kilifi, Kenya: a cross sectional observational study. PLoS One. 2017;12(5): e0177382.

53. WHO. Haemoglobin concentration for diagnosis of severe anaemia and assessment of severity. 2014. https://wwww.hoint/vmnis/indicators/ haemoglobinpdf. Accessed 23 Nov 2020.

54. Menendez C, Fleming AF, Alonso PL. Malaria-related anaemia. Parasitol Today. 2000;16(11):469-76.

55. Weatherall DJ, Miller LH, Baruch DI, Marsh K, Doumbo OK, Casals-Pascual C, et al. Malaria and the red cell. Hematol Am Soc Hematol Educ Program. 2002:35-57.

56. Wickramasinghe $\mathrm{SN}$, Abdalla $\mathrm{SH}$. Blood and bone marrow changes in malaria. Baillieres Best Pract Res Clin Haematol. 2000;13(2):277-99.

57. Wongtong N, Jones S, Deng Y, Cai J, Ataga Kl. Monocytosis is associated with hemolysis in sickle cell disease. Hematology. 2015;20(10):593-7.

58. Belcher JD, Marker PH, Weber JP, Hebbel RP, Vercellotti GM. Activated monocytes in sickle cell disease: potential role in the activation of vascular endothelium and vaso-occlusion. Blood. 2000;96(7):2451-9.

59. Inwald DP, Kirkham FJ, Peters MJ, Lane R, Wade A, Evans JP, et al. Platelet and leucocyte activation in childhood sickle cell disease: association with nocturnal hypoxaemia. Br J Haematol. 2000;111(2):474-81.

60. Wun T, Cordoba M, Rangaswami A, Cheung AW, Paglieroni T. Activated monocytes and platelet-monocyte aggregates in patients with sickle cell disease. Clin Lab Haematol. 2002;24(2):81-8.

61. Aidoo. Protective effects of the sickle cell gene against malaria morbidity and mortality. Lancet. 2002;359:1311-2.

62. Schmoeller D, Picarelli MM, Paz Munhoz T, Poli de Figueiredo CE, Staub HL. Mean Platelet Volume and Immature Platelet Fraction in Autoimmune Disorders. Front Med (Lausanne). 2017:4:146.

63. Ashley-Koch A, Yang Q, Olney RS. Sickle hemoglobin ( $\mathrm{HbS}$ ) allele and sickle cell disease: a HuGE review. Am J Epidemiol. 2000;151(9):839-45.

64. Carlson J, Nash GB, Gabutti V, al-Yaman F, Wahlgren M. Natural protection against severe Plasmodium falciparum malaria due to impaired rosette formation. Blood. 1994;84(11):3909-14.

65. Williams TN, Mwangi TW, Roberts DJ, Alexander ND, Weatherall DJ, Wambua $\mathrm{S}$, et al. An immune basis for malaria protection by the sickle cell trait. PLoS Med. 2005;2(5):e128.

\section{Publisher's Note}

Springer Nature remains neutral with regard to jurisdictional claims in published maps and institutional affiliations.

\section{Ready to submit your research? Choose BMC and benefit from:}

- fast, convenient online submission

- thorough peer review by experienced researchers in your field

- rapid publication on acceptance

- support for research data, including large and complex data types

- gold Open Access which fosters wider collaboration and increased citations

- maximum visibility for your research: over $100 \mathrm{M}$ website views per year

At BMC, research is always in progress.

Learn more biomedcentral.com/submissions 